\title{
Nematophagous fungi: Metarhizium anisopliae
}

\section{Gitanjali Devi}

\author{
Department of Nematology, Assam Agricultural University, Jorhat, India
}

\begin{abstract}
Plant-parasitic nematodes are major pests affecting many economically important crop productions throughout the world. Some chemicals are widely used against the phytonematodes. Because of hazardous effects of these compounds on human beings, animals and on the environment, there is a need to develop other control strategies. Biocontrol of phytonematodes is an important method among environment-friendly measures of nematode management. There are some soil-inhabiting fungi that have biocontrol potential on phytonematodes, which can be used for nematode management. The fungus Metarhizium anisopliae, originally is an entomopathogenic bioagent has been utilizing as bionematicides. The fungus produces some secondary metabolite which may play a role in pathogenicity. Biocontrol potential of this fungus on some phytonematodes has been reported and its utilization is a major approach towards sustainable and environment friendly agricultural production.
\end{abstract}

Keywords - Plant-parasitic nematodes, bionematicides, nematophagous fungi, Metarhizium anisopliae, entomopathogenic fungi.

\section{INTRODUCTION}

Plant parasitic nematodes are one of the major factors limiting the productivity of many agricultural crops (Luc et al., 2005). The majority of the synthetic chemical nematicides are being banned in the market because of their hazardous effect on human beings and animals (Ghazalbash and Abdollahi, 2011). Therefore there is a need for sustainable, effective, and environmentally acceptable nematode management options (Sikora and Fernandez, 2005). Large numbers of organisms including fungi, bacteria, viruses, insects, mites and some invertebrates have been found to invade or prey on the nematodes (Stirling, 1991). Some soil inhabiting fungi are pathogenic to some pests of plants, including insects and nematodes (Dijksterhuis et al., 1994). Fungi have a significant association with nematodes in rhizosphere and thus, they can constantly reduce the population of nematodes in nearly all soils in different geographical areas (Siddiqui and Mahmood, 1996). Although more than 70 genera and 160 species of fungi have been associated with nematodes, only a few of them are known as nematophagous fungi (Duddington, 1994). Fungi can directly parasitize nematodes (Holland et al., 1999; Olivares Bernabeu and Lopez-LIorca, 2002; Chen and Chen, 2003; Fatemy et al., 2005) or secrete ne maticidal metabolites and enzymes that affect nematode viability (Cayrol et al.,1989; Nitao et al., 1999; Chen et al., 2000). These active compounds have the potential for being applied as novel nematicides (Meyer et al., 2004).

\section{NEMATOPHAGOUS FUNGI: METARHIZIUM ANISOPLIAE}

Metarhizium anisopliae, the agent of green muscardine disease of insects, formerly known as Entomophthora anisopliae (basionym) (Metschnikoff, 1879), is a fungus that grows naturally in soils throughout the world and causes disease in various insects by acting as a parasitoid. It is the most important entomopathogenic fungus (Richards and Rogers, 1990; Driver et al., 2000; Liu et al., 2007; Hoe et al., 2009). Entomophthora anisopliae, later on renamed to $M$. anisopliae by Sorokin (1883). The fungus has mass growth on artificial culture media and produces abundant conidia, but the conidia only germinates in contact with their host (Farashiani et al., 2011).

\section{MODE OF ACTION AND EFFECTS ON NEMATODES}

The exact mode of action of $M$. anisopliae on nematodes is still unknown but it is likely similar to other fungi with sticky spores or conidia. The conidia germinate, parasitize and kill the cadaver, by direct penetration and producing the infective hyphae inside the nematode body. Prior to any direct attack to the host, the fungus produces destruxin $\mathrm{A}$ and destruxin B that can kill the host (Roberts, 1966). Kershaw et al., 1999 and Hsiao and Ko (2001) reported that this fungus produces some cyclic peptides, destruxins which may play a role in its pathogenicity. There are a few reports on impact of $M$. anisopliae on nematodes. Biological control of sugarcane nematodes using Penicillium oxalicum and $M$. anisopliae has been studied by Zorilla (2001). He has reported the significant inhibitory effect of $M$. anisopliae on the studied nematode population. The effect 
of this fungus against Rotylenchulus reniformis have been reported by Tribhuvaneshwar et al., (2008). They have reported that application of this bioagent reduced the final population of this plant parasitic nematode as well as some species of free-living nematodes. In a survey in BoyerAhmad region in Iran, some naturally infected nematodes to M. anisopliae were observed (Ghayedi and Abdollahi, 2013). They purified the isolated fungus and also they showed the biocontrol potential of the isolate on $J_{2} \mathrm{~S}$ of Heterodera avenae, with $47.1 \%$ parasitization. Biocontrol potential of M.anisopliae against some species of root knot nematodes has been shown (Jahanbazian et al., 2014; Jahanbazian et al., 2015). Greenhouse investigations showed that both bioagents Trichoderma harzianum and M. anisopliae caused significant decrease in nematode related factors including root gall, but the inhibition in root galling of tomato was more in case of M. anisopliae (Khosrawi et al.,2014).

\section{BIO-PRIMING EFFECTS OF $M$.} ANISOPLIAE

The capability of microorganism to colonizing the roots of plant is an important factor to have the promoting power (Schroth and Hancock, 1982). So me species of Metarhizium are attracted to roots of certain plant species (Wang and St Leger, 2007) and has root colonization ability (Bruck, 2005). Conidial germination and different rates of root colonizing by $M$. anisopliae isolates, has been reported (Elena et al., 2011; Sassan et al., 2012). Even some isolates of $M$. anisopliae have endophytic behavior (St. Leger, 2008). Bio-priming effects of $M$. anisopliae on germination and seedling growth of flax seed have been shown by Bakhit et al., (2015). The number of galls, egg masses and eggs of M.javanica were reduced in to mato roots by soil application of $M$. anisopliae spore suspension along with oak debris. The tomato roots have been colonized by M.anisopliae and the rate of nematode penetration to the roots was declined. Based on their reports, the growth of infected tomato plants has been improved after application of M. anisopliae (Abdollahi, 2018).

\section{CONCLUSION}

For a sustainable nematode management we have to isolate, mass produce and formulate the virulent strains of Metarhizium anisopliae which are environment friendly as well as cost effective. In near future $M$. anisopliae will provide a promising bionematicide which in turn improve plant growth and increase crop yield.

\section{REFERENCES}

[1] Abdollahi, M. 2018. Application of Metarhizium anisopliae against Meloidogyne javanica in soil amended with oak debris. International Journal of Agricultural and Biosystems Engineering 12(2): 3541.

[2] Bakhit, M., Moradi, A., and Abdollahi, M. 2015. Biopriming effects of Trichoderma harzianum and Metarhizium anisopliae on germination and seedling growth of flax seed. 4th National Congress on Medicinal Plants 12, 13 May 2015, Tehran, Iran.

[3] Bruck, D. J. 2005. Ecology of Metarhizium anisopliae in soilless potting media and the rhizosphere: implications for pest management. Biological Control 32: $155-163$.

[4] Cayrol, J.C., Djian, C.,and Pijarowski, L. 1989. Study of the nematicidal properties of the culture filtrate of the nematophagous fungus Paecilomyces lilacinus. Revue de Nematologie 12 (4): 331-336.

[5] Chen, S.Y.,and Chen F.J. 2003. Fungal parasitis $m$ of Heterodera glycines eggs as influenced by egg age and pre-colonization of cysts by other fungi. Journal of Nematoloy 35 (3): 271-277.

[6] Chen, S.Y., Dickson, D.W., and Mitchel, D.J. 2000. Viability of Heterodera glycines exposed to fungal filtrates. Journal of Nematoloy 32 (2): 190-197.

[7] Dijksterhuis, J., Veenhuis, M., Harder W., and Nordbring-Hertz, B. 1994. Nematophagous fungi: physiological aspects and structure-function relationships. Advances in Microbial Physiology 36: 111-143.

[8] Driver, F., Milner, R.J., Trueman, J.W.H. 2000. A taxonomic revision of Metarhizium based on a phylogenetic analysis of rDNA sequence data. Mycological Research 104 (2): 143-150.

[9] Duddington, C.L. 1994. Predacious fungi and nematodes. Experientia 18(12): 537-543.

[10] Elena, G. J., Beatriz, P. J., Ale jandro, P. and Lecuona, R. E. 2011. Metarhizium anisopliae (Metschnikoff) Sorokin promotes growth and has endophytic activity in to mato plants. Advances in Biological Research 5 (1): 22-27.

[11] Farashiani, M. E., Askary, H., Moniri,V. R., Omid, R., Azizkhani, E., Babmorad, M., Zamani, S. M., Hashemi, M. and Zeinali, S. 2011. Influence of super absorbent polymers on the pathogenicity of Metarhizium anisopliae (Metsch). Sorokin against Aeolesthes sarta (Col.: Cerambycidae). Iranian Journal of Forest and Range Protection Research 8(1): 27-38. 
[12] Fatemy, S., Saeidi-Naeini, F., and Alizadeh, A. 2005. In vitro screening of fungi for parasitis $m$ against sugar beet cyst nematode Heterodera schachtii.Nematologia Mediterranea 33: 185-190.

[13] Ghayedi, S. and Abdollahi, M. 2013. Biocontrol potential of Metarhizium anisopliae (Hypocreales: Clavicipitaceae), isolated from suppressive soils of Boyer- Ahmad region, Iran, against J2s of Heterodera avenae. Journal of Plant Protection Research 53 (2): $165-171$

[14] Ghazalbash N., and Abdollahi M. 2011. Botanicals from Ferulago angulata (Schlecht.) Boiss. and Zataria multiflora Boiss used as bio-nematicide, suitable substitutes for chemical pesticides.2nd International Congress of Food Hygiene. Tehran, Iran, April 30 May 1, 2011, p. 172.

[15] Hoe, P.K., Bong, C.F.J., Jugah, K., and Rajan, A. 2009. Evaluation of Metarhizium anisopliae var. anisopliae (Deuteromycotina: Hyphomycete) isolates and their effects on subterranean termite Coptotermes curvignathus (Isoptera: Rhinotermitidae). American Journal of Agricultural and Biological Sciences 4 (4): 289-297.

[16] Holland, R.J., Williams, K.L.,and Khan, A. 1999. Infection of Meloidogyne javanica by Paecilomyces lilacinus. Nematology 1 (2): 131-139.

[17] Hsiao, Y.M.,and Ko, J.L. 2001. Determination of destruxins, cyclic peptide toxins produced by different strains of Metarhizium anisopliae and their mutants induced by ethyl methane sulfonate and ultraviolet using HPLC method. Toxicon 39 (6): 837-841.

[18] Jahanbazian, L., Abdollahi, M., and Hussienvand, M. 2014. Inhibitory effect of Metarhizium anisopliae against Meloidogyne incognita, the causal agent of root knot of tomato, under laboratory condition. National Conference of Modern Topic in Agriculture. March 6 2014, Tehran, Iran.

[19] Jahanbazian, L., Abdollahi, M., and Rezaie, R. 2015. Combined effect of Metarhizium anisopliae and Pseudomonas fluorescens CHA 0 on root-knot nematode, Meloidogyne incognita in tomato. Iranian Journal of Plant Pathology 51(3): 339-355.

[20] Kershaw, M. J., Moorhouse, E. R., Bateman, R., Reynolds, S. E. and Charnley, A. K. 1999. The Role of destruxins in the pathogenicity of Metarhizium anisopliae for three species of insect. Journal of Invertebrate Pathology 74: 213-223.

[21] Khosrawi, M., Abdollahi, M. and Sadravi, M. 2014. Effect of Metarhizium anisopliae and Trichoderma harzianum on root knot nematode, Meloidogyne javanica. Biological Control of Pests and Plant Diseases 3(1): 67-76.

[22] Liu, B.L., Rou, T.M., Rao, Y.K., Tzeng, Y.M. 2007. Effect of $\mathrm{pH}$ and aeration rate on the production of Destruxins A and B from Metarhizium anisopliae. International Joumal of Applied Science and Engineering 5 (1): 17-26.

[23] Luc, M., Sikora, R.A., and Bridge, J. 2005. Plant Parasitic Nematodes in Subtropical and Tropical Agriculture. CABI Wallingford, UK, p. 871.

[24] Meyer, S.L.F., Huettel, R., Liu, X.Z., Hu mber, R.A., Juba, J., and Nitao, J. 2004. Activity of fungal culture filtrates against soybean cyst nematode and root-knot nematode egg hatch and juvenile motility. Nematology 6 (1): 23-32.

[25] Nitao, J.K., Meyer, S.L.F., and Chitwood, D.J. 1999. In vitro assays of Meloidogyne incognita and Heterodera glycines for detection of nematodeantagonistic fungal compounds. Journal of Nematology 31 (2): 172-183.

[26] Olivares-Bernabeu， C.M.,and Lopez-Llorca L.V. 2002. Fungal egg-parasites of plant-parasitic nematodes from Spanish soils. Revista Iberoamericana de Micologia 19 (2): 104-110.

[27] Richards, M. G. and Rodgers, P. B.1990. Commercial development of insect biocontrol agents. The exploitation of micro-organisms in applied biology. Aspects of Applied Biology 24: 245- 253.

[28] Roberts, D. W. 1966. Toxins from the entomogenous fungus Metarhizium anisopliae. 1. Production in submerged and surface cultures, and in inorganic and organic nitrogen media. Journal of Invertebrate Pathology 8: 212-221.

[29] Sasan, R. K. and Bidochka, M. J.2012. The insectpathogenic fungus Metarhizium robertsii (Clavicipitaceae) is also an endophyte that stimulates plant rootdevelopment. American Journal of Botany 99 (1): 101-107.

[30] Schroth, M. N. and Hancock, J. G.1982. Diseasesuppressive soil and root colonizing bacteria. Science 216: 1376-1381.

[31] Siddiqui, Z.A., and Mahmood, I. 1996. Biological control of plant parasitic nematodes by fungi: a review. Bioresource Technology 58 (3): 229-239.

[32] Sikora, R.A., and Fernandez E. 2005. Nematode parasites of vegetables. p. 319-392. In M. Luc, R.A. Sikora and J. Bridge (Eds.). Plant Parasitic Nematodes in Subtropical and Tropical Agriculture (2nd ed.) CABI Wallingford, UK. 
[33] Sorokin, N. 1883. Plant parasites causing infectious diseases of man and animals. Vyp. II. Izdanieglavnogo Voenno-Meditsinskago Upraveleneia. St Petersburg (First supplement) Journal of Military Medicine 1:168-198.

[34] St Leger, R. 2008. Studies on adaptations of Metarhizium anisopliae to life in the soil. Journal of Invertebrate Pathology 98: 271-276.

[35] Stiring, G.R. 1991. Biological Control of Plant Parasitic Nematodes: Progress, Problems and Prospects. Common wealth Agricultural Bureau International, Wallingford, Oxon, UK, p. 282.

[36] Tribhuvaneshwar Sharma, M. K. and Bhargava, S. 2008. Efficacy of green muscardine fungi,
Metarhizium anisopliae against reniform nematode, Rotylenchulus reniformis on to mato. Indian Journal of Nematology 38: 242-244.

[37] Wang, C. and St Leger, R. J. 2007. The MAD1 adhesion of Metarhizium anisopliae links adhesion with blastospore production and virulence to insects, and the MAD2 adhesion enables attachment to plants. Eukaryote Cell 6: 808-816.

[38] Zorilla, R.A. 2001. Monitoring and management of sugarcane diseases due to nematode. National crop protection center. University of the Philippines at Los Banos College, Laguna 4031, Philippines, p. 19. 